\title{
Peritopic anesthesia: a new alternative in cataract surgery
}

This article was published in the following Dove Press journal:

Clinical Ophthalmology

14 March 2013

Number of times this article has been viewed

José A Abreu'

Rodrigo Abreu ${ }^{2}$

Luis M Cordovés'

José J Aguilar'

'Ophthalmology Department, University Hospital of the Canary Islands, Tenerife, Canary Islands, Spain; ${ }^{2}$ Ophthalmology Department, University Hospital of La Candelaria

Tenerife, Canary Islands, Spain
Correspondence: José A Abreu Ophthalmology Department, University Hospital of the Canary Islands, Ctra. Ofra S/N La Cuesta, 38320 La Laguna,

Tenerife, Canary Islands, Spain

Email jaabreureyes@gmail.com

\section{Dear editor}

We read with interest the recently published article "Superior subconjunctival anesthesia versus retrobulbar anesthesia for manual small-incision cataract surgery in a residency training program: a randomized controlled trial" by Pipat Kongsap, ${ }^{1}$ where the author studied possible differences in the clinical outcomes of superior subconjunctival anesthesia and retrobulbar anesthesia, in a residency training program.

Nowadays, two options are the most accepted in phacoemulsification anesthesia: topical anesthesia and regional anesthesia (retrobulbar and peribulbar). ${ }^{2}$ However, being strict with the concepts, if we talk about topical anesthesia, we should refer only to use of anesthetic eyedrops, whereas when we add intracameral lidocaine and/or sedation, we should be talking about a "combined form." When topical anesthesia alone is not possible, rather than perform a classical retrobulbar or peribulbar anesthesia, we could choose an intermediate approach that would supplement the topical anesthesia with a "limited" peribulbar anesthesia, to provide their benefits without the associated drawbacks.

We would like to mention that for the last 5 years, we have added a new option to the anesthetic techniques discussed: peritopic anesthesia. ${ }^{3}$ Peritopic anesthesia, as defined by our group, is a combination of topical anesthesia and a single-injection peribulbar anesthesia, without sedation. The patient's eye is first instilled with a drop of a commercial mixture of tetracaine hydrochloride $0.1 \%$ and oxybuprocaine hydrochloride $0.4 \%$. A second and a third drop, instilled once the patient is in the operating room, contain a mixture of tetracaine hydrochloride $0.5 \%$ and naphazoline. Peribulbar anesthesia then involves an injection, at the inferotemporal quadrant, of $2-4 \mathrm{~mL}$ of a $50 \%$ mixture of lidocaine $2 \%$ and bupivacaine $0.5 \%$.

This anesthetic combination has the effect that after surgery, any limited induced akinesia has virtually disappeared, leaving a comfortable analgesia so that the patient will not feel the urge to rub the eye or tighten the eyelid in an antalgic maneuver - these would be dangerous occurrences in sutureless cataract surgery because they could lead to some degree of aqueous humor leakage, secondary hypotonia, intraocular lens malposition, increased risk of endophthalmitis, ${ }^{4}$ etc. Peritopic anesthesia doesn't produce postoperative ptosis, and eye occlusion is usually not needed, and both the patient and the surgeon are comfortable during the surgery.

This new anesthesia technique in cataract surgery may be useful when topical anesthesia is insufficient, as may occur in: uncooperative patients (anxiety, deafness, 
dementia, etc), associated ocular pathology (cornea abnormalities, uveitis, vitrectomy), presumed complicated cataract surgery, simultaneous cataract and glaucoma surgery, or when the surgeon is a resident or novice (the main interest of Dr Kongsap).

The choice of anesthetic technique should be based on the patient's needs and the surgeon preferences. ${ }^{5}$ We could consider peritopic anesthesia as another valid alternative in cataract surgery, with the advantages of topical anesthesia and without the complications of retrobulbar anesthesia, and it may be useful in many of our patients.

\section{References}

1. Kongsap P. Superior subconjunctival anesthesia versus retrobulbar anesthesia for manual small-incision cataract surgery in a residency training program: a randomized controlled trial. Clin Ophthalmol. 2012;6:1981-1986.

2. Crandall AS. Anesthesia modalities for cataract surgery. Curr Opin Ophthalmol. 2001;12(1):9-11.

3. Abreu JA, Aguilar JJ, Capote E, Abreu R. Peritopic anesthesia in cataract surgery. Arch Soc Esp Oftalmol. 2009;84(2):63-64. Spanish.

4. Garcia-Arumi J, Fonollosa A, Sararols L, et al. Topical anesthesia: possible risk factor for endophthalmitis after cataract extraction. J Cataract Refract Surg. 2007;33(6):989-992.

5. Rizzo L, Marini M, Rosati C, et al. Peribulbar anesthesia: a percutaneous single injection technique with a small volume of anesthetic. Anesth Analg. 2005;100(1):94-96.
Clinical Ophthalmology

\section{Publish your work in this journal}

Clinical Ophthalmology is an international, peer-reviewed journal covering all subspecialties within ophthalmology. Key topics include: Optometry; Visual science; Pharmacology and drug therapy in eye diseases; Basic Sciences; Primary and Secondary eye care; Patient Safety and Quality of Care Improvements. This journal is indexed on

\section{Dovepress}

PubMed Central and CAS, and is the official journal of The Society of Clinical Ophthalmology (SCO). The manuscript management system is completely online and includes a very quick and fair peer-review system, which is all easy to use. Visit http://www.dovepress.com/ testimonials.php to read real quotes from published authors. 